\title{
Analysis of the Predictive Role of Teachers' Effective Communication Skills and Motivation Levels on Classroom Management Profiles
}

\author{
Neslin İhtiyaroğlu ${ }^{1}$ \\ ${ }^{\prime}$ Krrlkkale University, Faculty of Education, Educational Administration Department, Kirlkkale, Turkey \\ Email:neslin52@gmail.com
}

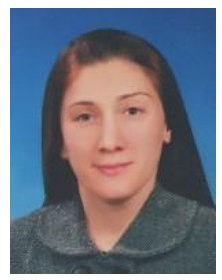

\begin{abstract}
The aim of this study is to determine the predictive role of teachers' effective communication skills and motivation levels on classroom management profiles. In the research, relational screening model was used. The population of the study consists of 1575 teachers working in Etimesgut, Ankara in the 2017-2018 academic years and the sample of the study consists of 294 teachers selected by convenience sampling method. The data required for the research were collected using the Effective Communication Skills Scale, Adult Motivation Scale and Classroom Management Profile Scale. Correlation and stepwise regression analysis were used for data analysis. In the analyzes conducted, it is seen that the variable with the highest mean is effective listening dimension in the effective communication skills, intrinsic motivation dimension in motivation and classroom management profile sub-dimension which is authoritative classroom management profiles dimension in the classroom management profiles. According to the results of the correlation analysis, the highest relations are between authoritarian classroom management profile and extrinsic motivation; authoritative classroom management profile and I-language. According to the results of stepwise regression analysis, effective communication skills and motivation only predict the indifferent classroom management profile together. At the end of the study, suggestions for increasing effective communication skills and motivation levels of teachers were presented.
\end{abstract}

Keywords: Effective communication skills, Motivation, Authoritarian classroom management profile, Authoritative classroom management profile, Laissez-faire classroom management profile, Indifferent classroom management profile.

Citation | Neslin İhtiyaroğlu (2019). Analysis of the Predictive Role of Teachers' Effective Communication Skills and Motivation Levels on Classroom Management Profiles. Journal of Education and eLearning Research, 6(1): 17-25.

History:

Received: 17 October 2018

Revised: 21 November 2018

Accepted. 31 December 2018

Published. 7 Marcher

Licensed: This work is licensed under a Creative Commons

Attribution 3.0 License $(\mathrm{cc})$

Publisher: Asian Online Journal Publishing Group

\section{Contents}

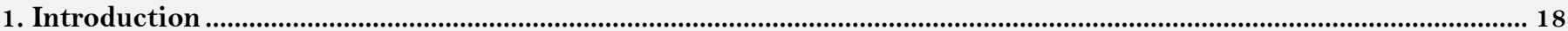

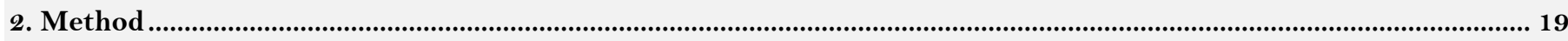

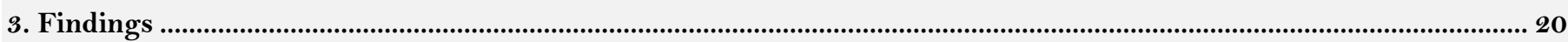

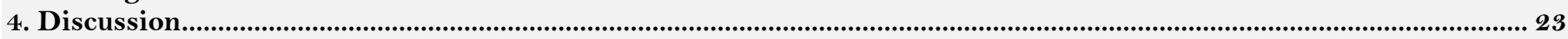

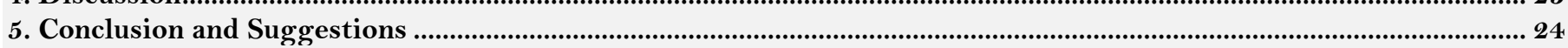

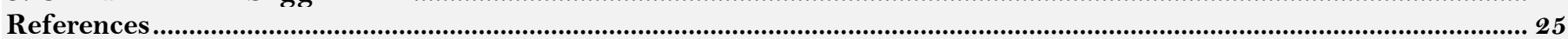

Funding: This study received no specific financial support.

interests regarding the publication of this paper: Transparency: The author confirms that the manuscript is an honest, accurate, and transparent account of the study was reported; that no vital features of the study have been omitted; and that any discrepancies from the the explained.

thical: This study follows all ethical practices during writing. 


\section{Contribution of this paper to the literature}

This study contributes to the existing literature by determining the predictive role of teachers' effective communication skills and motivation levels on classroom management profiles.

\section{Introduction}

The ultimate goal of education is to create processes in which students achieve a high level of gain. In shaping these processes, teachers have the most important roles and tasks. Considered that teachers only influence student learning even with their behavior (Gorham and Christophel, 1990) and that the best learning is done in the bestmanaged classes (Ming-Tak and Wai-Shing, 2008) teachers' influence on learning is better understood. Giving positive quality to this effect is possible with the effective management processes in the classroom, that is, teachers' classroom management skills.

Classroom management can be defined as the mobilization of all equipment, item source, and students, human resource, in the classroom environment to achieve the highest level of gain (Demirtaş, 2005). Classroom management processes include the organization of classroom life, programming of education, organizing procedures and resources, setting up an environment for effectiveness, directing student development, and taking measures to anticipate problems in the classroom (DiGiulio, 2000). These practices for effective classroom management contribute to the individual, social, cultural and democratic development of students by increasing the effect of educational activities (Güneş, 2007).

It is a variable covering many different fields of classroom management. These fields of study can be listed as professional dominance, goal-directed behavior, classroom leadership, planning, classroom communication, classroom behavior management, event management, time management and evaluation (Cubukçu and Girmen, 2008). Effective management in the classroom requires high levels of teachers' competence in all areas.

Teachers benefit from different models and approaches in the classroom management process. These models and approaches are classified by different researchers and there are common points in classifications as well as differentiations. Baumrind (1966) created three different models with a focus on warmth and control. In the first model called permissive model, the warmth is high and the control is low. For this reason, teachers prioritize student freedoms and teachers' expectations for directing student behavior are very limited. In the authoritarian model, the warmth is low and the control is high. In this model, student autonomy is perceived as an unnecessary or damaging factor, and the teacher tries to shape the student behavior within the framework of certain standards. In the authoritative model, both warmth and control are high. Therefore, this model emphasizes both autonomy and discipline. While the teacher presents his/her perspective in the classroom, he/she does not ignore the students' interests and thoughts. In another classification called the Dreikurs (1968); Dreikurs (1968) suggested that teachers exhibited three types of behavior as autocratic, democratic, and permissive in the classroom setting. Autocratic teachers are the only authorized person in the decision-making process, and students are not involved in this process. In the classroom there is a climate of fear and obedience, and students are in learned helplessness, so the academic achievement in such classes is quite low. Democratic teachers show with all the behaviors that he/she is the member or the part of the classroom. Students' feelings and thoughts are at the forefront and participation rates are quite high. Therefore, a climate with high success and confidence is dominant in the classroom. Permissive teachers do not make a positive or negative contribution to the process in the classes. Due to the lack of rules and goals, irregularity and chaos dominate in the classrooms. Bull and Solity (1996) examined teacher behaviors in two models as "deviance-insulative" and "deviant provocative". Deviance-insulative model includes democratic teacher behaviors. In an environment based on respect and tolerance, teachers support student behavior towards achievements and make efforts to gain students who behave otherwise. Deviant provocative teachers tend to find fault, to have destructive criticism and to display judgmental attitudes. A negative climate prevails in the classroom due to degrading and punitive behavior. Kris (1996) examined the teachers' classroom management profiles in four groups: authoritarian, authoritative, laissez-faire and indifferent classroom management profiles. In the authoritarian classroom management profile, the teacher exhibits restrictive and controlling behaviors and expects the students to obey the rules without question. In the authoritative classroom management profile, teachers' sincere and supportive behaviors are in the foreground. Teachers often explain the reasons behind the classroom rules; allow students to present their ideas by building constructive discussion environments and encourage students to be raised as self-confident individuals by taking into account student ideas. In the laissezfaire classroom management profile, the teacher is the only audience. The demands of the teachers on the students and their behaviors towards keeping the students under control are very limited. The relationship between teacher and student is based on friendship. Students' feelings are at the forefront. Due to the permissive practices in the classroom, the students think that they will get what they want. Student motivations in such classes are quite low. Teachers' insensitive behavior is in the forefront in the indifferent classroom management profile. These teachers do not want to prepare for the lesson, develop materials or use tools in the course. The aim of the course is only to complete the course duration. In these environments where student learning is not important, each student is responsible for his/her learning. In this research, the classroom management profiles were examined according to classification created by Kris (1996).

Teachers' classroom management skills are influenced by many variables and affect many variables. Aküzüm and Ozdemir (2017) investigated the relationship between teachers' communication skills and classroom management skills. In the study, it was determined that effective communication skills examined with empathy, transparency, equality, efficiency, competence sub-dimensions predicted classroom management skills of teachers examined with physical arrangement of classroom, learning-teaching process, time management, behavior management and motivation sub-dimensions and described variance was found to be $67 \%$. This result showed that teachers' effective classroom management was closely related to the effective communication skills.

Communication can be defined as a process in which a person communicates by making connecting with another person and the meaning is replaced by the use of common symbols among people (Adair, 2013) or as shaping the emotions of both the communicator and the person receiving the message (Planalp, 1999). In 
education, communication can be defined as the process of sharing feelings, thoughts and information to contribute to the targets. In communication process, teachers can meet the needs in the terms of motivation, knowledge, selfreliance, relationship building or the teacher may cause students to suffer from unwillingness, loss of confidence, belonging and communication desire (Jones, 2007). In the light of these studies, it can be concluded that the communication skills of the teachers support both the development of students and their individual development.

In this research, effective communication skills of teachers were examined in five sub-dimensions: ego supportive language, active-participative listening, self-recognition/self-disclosure, empathy and I-language. In ego supportive language, individuals' shortcomings are told by emphasizing their positive characteristics and high performances so it is prevented that they feel inadequate. Active-participative listening expresses the listening process in which the listener plays an active role in the communication process, the motivation to perceive the message is sufficient and the attention is at the highest level. Self-recognition/self-disclosure is about the person's self- awareness and transparency in communication. Empathy is the ability of a person to put himself/herself in somebody's shoes and perceive events and situations according to their point of view. I-language is to convey the meanings by emphasizing the effect of the unwanted situation on the speaker without using the expressions for judgment, criticism and accusation (Buluş et al., 2017).

Another variable that affects teachers' classroom management skills is the level of motivation (Biçaku, 2015). Motivation can be defined as initiating, continuing and constructing a certain movement (Eren, 2000) as the intensity, direction and continuity of the effort in a target (Slavin, 2013) and as the cause or power to turn towards something and act on it Gibson et al. (1997). Tauber (2007) examined motivation in two ways as intrinsic and extrinsic motivation. Intrinsic motivation is the behavior of the individual without depending on any external cause. Intrinsic motivation sources can be listed as talent, personality structure, psychological needs, beliefs and values, expectations, dreams and experiences (Tuzcuoglu, 2014). Extrinsic motivation is that the individual needs the effects of external factors and behaves accordingly. Extrinsic motivation sources can be listed award, punishment, appreciation, acceptance, pressure and request (Eren, 2018). In this research, the motivation levels of teachers are examined as intrinsic and extrinsic motivation.

Teachers' motivation levels are closely related to the quality of education (Javaid, 2009). Because the motivation levels of teachers have predictive roles on many factors related to education process. Researches indicated that motivation level of teachers are positively related to teaching approaches (Han et al., 2015) and teaching methods (Hein et al., 2012). Based on these studies, it is thought that the motivation levels of the teachers can be related to the classroom management profiles.

Based on the fact that teachers affect students' learning only even with their behaviors, examining the predictive roles of effective communication skills and motivation levels of teachers on classroom management profiles is thought important to increase awareness of teachers about the development of effective classroom management skills and to show what factors should be focused on the development of these skills. In this context, this research aims to examine the predictive role of teachers' communication skills and motivation levels on classroom management profiles. In order to achieve this goal, the following questions were sought:

1) 1) What is the level of effective teachers' communication skills, motivation and classroom management profiles?

2) Is there a significant relationship between teachers' communication skills, motivation levels and class management profiles?

3) Are teachers' communication skills and motivation levels a significant predictor of classroom management profiles?

\section{Method}

\subsection{Research Model}

This research was designed in relational screening model. The purpose of the relational survey model is to examine the existence and degree of the relationship between two or more variables (Karasar, 2009) without any intervention (Büyüköztürk et al., 2008).

\subsection{Population and Sample}

The population of the study consists of 1575 teachers working in the formal high schools in Etimesgut district of Ankara in the 2017-2018 academic year. Yazıcıoğlu and Erdoğan (2004) emphasized that in the population of which size is between 1000-2500, with $\alpha=0.05,{ }_{+}^{-0.05}$ sampling error and $p=0.3, q=0.7$ values, 286 sampling size is adequate. For this reason, the sample of the study consisted of 294 teachers who were determined by simple random sampling and gave feedback to the scales. Demographic characteristics of teachers are given in Table 1:

Table-1. Demographic features.

\begin{tabular}{|c|c|c|c|}
\hline \multicolumn{2}{|c|}{ Variables } & \multirow{2}{*}{$\begin{array}{c}\mathbf{n} \\
84 \\
\end{array}$} & \multirow{2}{*}{$\frac{\%}{28,6}$} \\
\hline Gender & Female & & \\
\hline & Male & 210 & 71,4 \\
\hline \multirow{4}{*}{ Age } & $20-30$ & 56 & 19,0 \\
\hline & $31-40$ & 91 & 31,0 \\
\hline & $41-50$ & 140 & 47,6 \\
\hline & $51-60$ & 7 & 2,4 \\
\hline \multirow{6}{*}{ Seniority } & $1-5$ & 49 & 16,7 \\
\hline & $6-10$ & 35 & 11,9 \\
\hline & $11-15$ & 70 & 23,8 \\
\hline & $16-20$ & 49 & 16,7 \\
\hline & $21-25$ & 56 & 19,0 \\
\hline & 25 and more & 35 & 11,9 \\
\hline
\end{tabular}




\subsection{Data Collection Tools}

In order to collect the necessary data for the research, three measurement tools were used for teachers. They are The Effective Communication Skills Scale developed by Buluş et al. (2017) Adult Motivation Scale developed by Tulunay and Ihtiyaroğlu (2019) and The Classroom Management Profiles Scale developed by Kris (1996) and adapted to Turkish by Ekici (2004).

Effective Communication Skills Scale: The scale consists of five dimensions and 34 items, including ego supportive language (6 items), active-participative listening ( 8 items), self-recognition/self-disclosure (5 items), Empathy (8 items) and I Language (7 items) and it is a 5-point Likert-type scale. In validity-reliability analyses conducted by Buluş et al. (2017) the factor loads of the items in the scale vary between .40 and .90 , item correlation coefficients vary between .32 and .60 and Cronbach's Alpha reliability coefficients of sub-dimensions vary between .72 and .85 . In the validity-reliability analyses conducted in this research, the factor loads of items vary between .30 and .90, item correlation coefficients vary between .14 and .79 and Cronbach's Alpha reliability coefficients of subdimensions vary between .71 and .88

Adult Motivation Scale: The scale consists of two dimensions and 21 items, including Intrinsic Motivation (13 items) and Extrinsic Motivation (8 items) and it is a 5-point Likert-type scale. In validity-reliability analyses conducted by Tulunay and Ihtiyaroğlu (2019) the factor loads of the items in the scale vary between .40 and .77; item correlation coefficients vary between .42 and .72; Cronbach's Alpha reliability coefficient of intrinsic motivation is .92 and extrinsic motivation is .82 . In the validity-reliability analyses conducted in this research, the factor loads of items vary between .30 and .93, item correlation coefficients vary between .12 and .95; Cronbach's Alpha reliability coefficient of intrinsic motivation is .95 and extrinsic motivation is .84 .

Classroom Management Profile Scale: The scale consists of four dimensions and 12 items, including authoritarian (3 items), authoritative (3 items), laissez-faire (3 items) and indifferent (3 items) classroom management profile and it is a 5-point Likert-type scale. In validity-reliability analyses conducted by Ekici (2004) Cronbach's Alpha reliability coefficient of authoritarian classroom management profile is .80; authoritative classroom management profile is .79; laissez-faire classroom management profile is .82 and indifferent classroom management profile is .81 . In the validity-reliability analyses conducted in this research, the factor loads of items vary between .30 and .74; item correlation coefficients vary between .14 and .62; Cronbach's Alpha reliability coefficients of sub-dimensions vary between .72 and .81 .

\subsection{Data Analysis}

The data obtained from the applied scales were tested using SPSS 20 package program. In this research, the levels of effective communication skills, motivations and classroom management profiles of teachers were determined with the arithmetic mean. Correlation analysis reveals the degree and direction of the relationship between teachers' effective communication skills, motivations and classroom management profiles. Stepwise regression analysis was used to determine the predictive role of effective communication skills and motivation on classroom management profiles.

\section{Findings}

This section presents the findings of the study questions. In the first part, the mean and standard deviation values of effective communication skills, motivation level and teachers' classroom management profiles are given. In the second part, correlation analysis results showing the relationship of variables with each other and predictive role of teachers' effective communication skills and motivation on classroom management profile.

\subsection{Mean and Standard Deviation Values for Variables}

Table 2 shows the mean and standard deviation values of variables:

Table-2. Mean and Standard Deviation Values for Variables

\begin{tabular}{|c|c|c|c|c|}
\hline \multicolumn{2}{|c|}{ Variables } & \multirow{2}{*}{$\frac{\mathbf{n}}{294}$} & \multirow{2}{*}{$\frac{\bar{X}}{4.31}$} & \multirow{2}{*}{$\frac{\mathbf{S}}{.76}$} \\
\hline \multirow{5}{*}{ Effective Communication Skills } & Ego Supportive Language & & & \\
\hline & Active-Participative Listening & 294 & 4.33 & .75 \\
\hline & Self-Recognition/Self-Disclosure & 294 & 3.97 & .67 \\
\hline & Empathy & 294 & 4.05 & .56 \\
\hline & I-Language & 294 & 3.81 & .47 \\
\hline & Effective Communication Total & 294 & 4.11 & .48 \\
\hline & Intrinsic Motivation & 294 & 4.35 & .73 \\
\hline \multirow[t]{2}{*}{ Motivation } & Extrinsic Motivation & 294 & 4.04 & .69 \\
\hline & Motivation Total & 294 & 4.23 & .65 \\
\hline \multirow{4}{*}{ Classroom Management Profile } & Authoritarian Classroom Management & 294 & 3.31 & .56 \\
\hline & Authoritative Classroom Management & 294 & 3.89 & .86 \\
\hline & Laissez-Faire Classroom Management & 294 & 3.25 & .93 \\
\hline & Indifferent Classroom Management & 294 & 2.84 & .84 \\
\hline
\end{tabular}

When Table 2 is examined, it is seen that the variables with the highest mean in effective communication skills is active-participative listening $(\bar{X}=4.33)$, in motivation is intrinsic motivation $(\bar{X}=4.35)$, in classroom management profiles is authoritative classroom management profile $(\bar{X}=3.89)$ and the variables with the lowest mean in effective communication skills is I-Language $(\bar{X}=43.81)$, in motivation is extrinsic motivation $(\bar{X}=4.04)$, in class management profiles is indifferent classroom management profile $(\bar{X}=2.84)$. 
3.2. Relationships between Effective Communication Skills and Motivation Levels of Teachers and Classroom Management Profiles

The results of the correlation analysis which reveal the relationship between teachers' effective communication skills, motivation levels and classroom management profiles are given in Table 3.

+ When Table 3 is examined, it is seen that the highest relationship is between effective communication skills and motivation $(\mathrm{r}=.80 ; \mathrm{p}<.01)$. When the relationships between classroom management profiles and other variables are examined, the highest relations are between authoritarian classroom management profile and extrinsic motivation $(\mathrm{r}=-.31 ; \mathrm{p}<.01)$; between authoritative classroom management profile and I-Language $(\mathrm{r}=$ $.31 ; \mathrm{p}(.01)$, between self-recognition/ self-disclosure and laissez-faire $(\mathrm{r}=.-.19 ; \mathrm{p}<.01)$, indifferent $(\mathrm{r}=-.23 ; \mathrm{p}$ $<.01)$ classroom management profile. On the other hand, the highest relationship in the total scores, is between effective communication skills total score and the authoritative classroom management profile $(\mathrm{r}=.16 ; \mathrm{p}<.01)$; between motivation total score and authoritarian classroom management profile $(\mathrm{r}=-.18 ; \mathrm{p}<.01)$.

The results of the stepwise regression analysis related to predictive role of the teachers' effective communication skills and motivation levels on the classroom management profiles are given in Table 4: 
Journal of Education and e-Learning Research, 2019, 6(1): 17-25

\begin{tabular}{|c|c|c|c|c|c|c|c|c|c|c|c|c|c|}
\hline Variables & 1 & 2 & 3 & 4 & 5 & 6 & 7 & 8 & 9 & 10 & 11 & 12 & 13 \\
\hline 1. Ego Supportive Language & 1 & $.76^{* * *}$ & $.27 * *$ & $.45 * *$ & $.33^{* * *}$ & $.75^{* *}$ & $.51 * *$ & -.08 & $.16^{* * *}$ & .07 & .02 & & \\
\hline 2.Active-Participative List. & & 1 & $.36^{* *}$ & $.52^{* * *}$ & $.19^{* * *}$ & $.77^{* *}$ & $.54 * *$ & $-.22 * *$ & .08 & .06 & .00 & & \\
\hline 3.Self-Recognition/Disclosure & & & 1 & $.42^{* * *}$ & $.40^{* * *}$ & $.42^{* * *}$ & .20 ** & -.08 & .10 & $-.19^{* *}$ & $-.23 * *$ & & \\
\hline 4. Empathy & & & & 1 & $.34 * *$ & $.53^{* *}$ & $.50^{* * *}$ & -.01 & .07 & -.05 & .08 & & \\
\hline 5. I-Language & & & & & 1 & $.31 * *$ & $.25 * *$ & .05 & $.31 * *$ & $.13^{* *}$ & $.13^{*}$ & & \\
\hline 6. Intrinsic Motivation & & & & & & 1 & $.61 * *$ & -.07 & $.26^{* * *}$ & $.17^{* * *}$ & $-.12^{*}$ & & \\
\hline 7. Extrinsic Motivation & & & & & & & 1 & $-.31 * *$ & -.03 & .07 & -.16 *** & & \\
\hline 8. Authoritarian Classroom Man & & & & & & & & 1 & $.18^{* *}$ & -.07 & $-.34 * * *$ & $-.12^{*}$ & $-.18 * *$ \\
\hline 9. Authoritative Classroom Man. & & & & & & & & & 1 & $-.48^{* * *}$ & $-.19^{* * *}$ & $.16^{* * *}$ & $.17 * *$ \\
\hline 10. Laissez-Faire Classroom M. & & & & & & & & & & 1 & $-.28 * *$ & $.13^{*}$ & $.15 *$ \\
\hline 11. Indifferent Classroom Man. & & & & & & & & & & & 1 & .10 & $-.15 *$ \\
\hline 12. Effective Comm. Total & & & & & & & & & & & & 1 & $.80^{* * *}$ \\
\hline 13.Motivation Total & & & & & & & & & & & & & 1 \\
\hline
\end{tabular}

13.Motivation Total 
Table-4. Results of Stepwise Regression Analysis.

\begin{tabular}{|c|c|c|c|c|c|c|c|c|c|c|}
\hline $\begin{array}{l}\text { Classroom } \\
\text { Management Profiles }\end{array}$ & Model & Predictors & B & $\boldsymbol{S E}$ & $\boldsymbol{\beta}$ & $\mathbf{t}$ & $p$ & $\mathbf{R}$ & $\mathbf{R}^{2}$ & Std. Error \\
\hline \multirow{5}{*}{$\begin{array}{l}\text { Authoritarian } \\
\text { Classroom Management } \\
\text { Profile }\end{array}$} & \multirow{2}{*}{1} & Constant & 3.87 & .28 & & 13.84 &. .00 & \multirow{2}{*}{.12} & \multirow{2}{*}{.01} & \multirow{2}{*}{.55} \\
\hline & & Effective Com. Skills & -.14 & 0.7 & -.12 & -2.01 & .05 & & & \\
\hline & \multirow{3}{*}{2} & Constant & 3.82 & .28 & & 13.77 & .00 & \multirow{3}{*}{.18} & \multirow{3}{*}{.03} & \multirow{3}{*}{.55} \\
\hline & & Effective Com. Skills & .08 & .11 & .07 & .75 & .45 & & & \\
\hline & & Motivation & -.20 & .08 & -.24 & -2.48 & .01 & & & \\
\hline \multirow{5}{*}{$\begin{array}{l}\text { Authoritative } \\
\text { Classroom Management } \\
\text { Profile }\end{array}$} & \multirow{2}{*}{1} & Constant & 2.67 & .43 & & 6.20 & .00 & \multirow{2}{*}{.16} & \multirow{2}{*}{.03} & \multirow{2}{*}{.85} \\
\hline & & Effective Com. Skills & .30 & .10 & .16 & 2.84 & .01 & & & \\
\hline & \multirow{3}{*}{2} & Constant & 2.70 & .43 & & 6.27 & .00 & \multirow{3}{*}{.18} & \multirow{3}{*}{.03} & \multirow{3}{*}{.85} \\
\hline & & Effective Com. Skills & 14 & .17 & .08 & .79 & .43 & & & \\
\hline & & Motivation & .15 & .13 & .11 & 1.17 & .24 & & & \\
\hline \multirow{5}{*}{$\begin{array}{l}\text { Laissez-Faire Classroom } \\
\text { Management Profile }\end{array}$} & \multirow{2}{*}{1} & Constant & 2.26 & .47 & & 4.84 & .00 & \multirow{2}{*}{.13} & \multirow{2}{*}{.02} & \multirow{2}{*}{.92} \\
\hline & & Effective Com. Skills & .24 & .11 & -.13 & -2.15 & .03 & & & \\
\hline & \multirow{3}{*}{2} & Constant & 2.30 & .47 & & 4.93 & .00 & \multirow{3}{*}{.15} & \multirow{3}{*}{.02} & \multirow{3}{*}{.92} \\
\hline & & Effective Com. Skills & .04 & .19 & .02 & .20 & .85 & & & \\
\hline & & Motivation & .19 & .14 & .14 & 1.40 & .16 & & & \\
\hline \multirow{5}{*}{$\begin{array}{l}\text { Indifferent } \text { Classroom } \\
\text { Management Profile }\end{array}$} & \multirow{2}{*}{1} & Constant & 2.14 & .42 & & 5.07 & .00 & \multirow{2}{*}{.10} & \multirow{2}{*}{.01} & \multirow{2}{*}{.84} \\
\hline & & Effective Com. Skills & .17 & .10 & -.10 & -1.7 & .00 & & & \\
\hline & \multirow{3}{*}{2} & Constant & 1.97 & .39 & & 5.02 & .00 & & & \\
\hline & & Effective Com. Skills & 1.03 & .16 & -.59 & -6.59 & .00 & .39 & .15 & .78 \\
\hline & & Motivation & -.79 & .12 & -.61 & -6.89 & .00 & & & \\
\hline
\end{tabular}

When the first model for authoritarian classroom management profile is examined in Table 4, there is a weak and significant relationship between effective communication skills and authoritarian classroom management profile $\left(R=.12 ; R^{2}=.01 ; p<.01\right)$. Effective communication skills explain $01 \%$ of the total variance of authoritarian classroom management profile. In the second model, the addition of motivation to the model along with effective communication skills increased the variance from .01\% to .03\%. This shows that motivation contributes .02\% contribution to the explained variance. According to the standardized regression coefficient $(\beta)$, the relative order of predictive variables on authoritarian classroom management is motivation and effective communication skills. When the t-test results related to the significance of the regression coefficients are examined, it is seen that only motivation has a predictive role on the authoritarian classroom management profile ( $p>$. 01$)$.

When the first model for authoritative classroom management profile is examined in Table 4, there is a weak and significant relationship between effective communication skills and authoritative classroom management profile $\left(R=.16 ; R^{2}=.03 ; p<.01\right)$. Effective communication skills explain $03 \%$ of the total variance of authoritative classroom management profile. When the second model is examined, variance explained has not changed with the addition of motivation to model. This shows that motivation does not contribute to the variance explained. According to the standardized regression coefficient $(\beta)$, the relative order of predictive variables on authoritative classroom management is motivation and effective communication skills. When the t-test results of the significance related to the regression coefficients are examined, it is revealed that effective communication skills and motivation do not have a predictive role on authoritative classroom management profile $(\mathrm{p}>$. 01).

The first model of laissez-faire classroom management profile in Table 4 reveals that effective communication skills provide a weak and meaningful relationship with the laissez-faire classroom management profile $(\mathrm{R}=.13$; $\mathrm{R} 2$ $=.02 ; \mathrm{p} \mathrm{<.01)}$. Effective communication skills explain $02 \%$ of the total variance of laissez-faire classroom management profile. As a result of the addition of motivation to the model, variance explained has not changed in the second model. This shows that motivation does not contribute to the variance explained, as in the case of authoritative classroom management profile. According to the standardized regression coefficient $(\beta)$, the relative order of predictive variables on laissez-faire classroom management is motivation and effective communication skills. When the t-test results related to the significance of the regression coefficients are examined, it is revealed that effective communication skills and motivation do not have a predictive role on laissez-faire classroom management profile ( $\mathrm{p}>$. 01$)$.

The first model of indifferent classroom management profile in Table 4 reveals that effective communication skills provide a weak and meaningful relationship with the indifferent classroom management profile $\left(R=.10 ; R^{2}\right.$ $=.01 ; p<.01)$. Effective communication skills explain $01 \%$ of the total variance of indifferent classroom management profile. In the second model, the addition of motivation to the model along with effective communication skills increased the variance from $01 \%$ to $15 \%$. This shows that motivation contributes $14.99 \%$ contribution to the explained variance. According to the standardized regression coefficient $(\beta)$, the relative order of predictive variables on indifferent classroom management is motivation and effective communication skills. When the t-test results of the significance of the regression coefficients are examined, it is found out that effective communication skills and motivation have predictive role on indifferent class management profile $(p<.01)$.

\section{Discussion}

In this research, studied the predictive role of teachers' communication skills and motivation levels on over classroom management profiles, it was found that the variable with the highest mean effective communication skills is active-participative listening in effective communication skills. Based on the support of effective listening skills to the agreement between individuals (Gordon, 2013) it can be said that active listening contributes to the development of positive relations between teachers and students. Active-participative listening skills play an important role in facilitating student learning, in the development of students' inquisitive cognition, in creating an environment where discussion, questioning and research are supported and where students feel free (Gordon, 2013). Therefore, it can be said that the teachers participating in this research support the student learning thanks 
to active-participative listening. In the motivation dimension, the variable with the highest mean is intrinsic motivation. Teachers' intrinsic motivation is high-level. Similarly, in the other studies (Argon and Erturk, 2013; Ertürk, 2016) it was concluded that the teachers' intrinsic motivation was high-level. The findings of these studies support the finding of this research. Teachers' high level of intrinsic motivation reveals that teachers do not need any external stimuli in behavior development. In the light of this result, it can be said that the teachers participating in the research have the power to reveal their capacities and to realize themselves. Hackman and Oldham (1980) emphasized that employees with intrinsic motivation have high levels of emotion about the significance of the job, that they are ready to take responsibility for the conclusion of the work and exhibit behaviors towards obtaining information with the result of activities. Therefore, teachers who have high intrinsic motivation compared to other teachers are more likely to have high performance, willingness to reach goals and take responsibility for the results. Authoritative classroom management profile has the highest mean in classroom management profiles dimension. Other studies (Ekici, 2004; Yilmaz, 2011; Ihtiyaroğlu, 2018) confirm that teachers use the most widely authoritative classroom management profile. It can be said that the teachers create constructive environments with their sincere and supportive behaviors and thus the students express their ideas freely and their self-confidence levels increase.

Another result of this research is that the highest relationship is between effective communication and authoritative classroom management profile positively and between motivation and authoritarian classroom management profile negatively. Teachers' supportive and sincere attitudes are at the forefront in authoritative classroom management profile. The classroom environment is designed to make learning easier and to help students feel free and safe (Kris, 1996). Considering that effective communication consists of teacher skills such as ego supportive language, active-participative listening, self-recognition/self-disclosure, empathy and I language, it can be said that these skills will contribute to authoritative classroom management profile.

In the authoritarian classroom management profile, limiting and controlling behaviors of teachers are in the forefront and students are expected to obey the rules without questioning them in the classroom (Kris, 1996). Considering the importance of teacher motivation in supporting the development of education, achievement and satisfaction (Jesus and Conboy, 2001). It can be said that the low-level motivation of teachers may cause the behaviors of the authoritarian classroom management profile.

In this research, it is concluded that effective communication skills predict authoritarian, authoritative and laissez-faire classroom management profiles. Effective communication skills predict authoritarian and laissez-faire classroom management profiles negatively and authoritative classroom management profile positively. In view of the dimensions of effective communication, it cannot be said teachers have effective communication skills who adopt authoritarian classroom management profile in which teachers are at the center and assume a rule-making role and who adopt laissez-faire classroom management profile in which teachers' demands are limited, teachers create environments where students can easily do whatever they want, and that teachers take on a permitting role. Particularly ego supportive language, self-recognition/self-disclosure and empathy sub-dimensions contradict teacher behaviors that adopt authoritarian classroom management profile; active-participative listening, I-language and empathy sub-dimensions contradict teacher behaviors that adopt laissez-faire classroom management profile. On the contrary, it will be easier for a teacher having effective communication skills to adopt authoritative classroom management profile based on supporting students' learning and establishing sincere and intimate relationships with students.

In this study, it is concluded that teachers' effective communication skills and motivation together predict only indifferent classroom management profile. In indifferent classroom management profile, teachers exhibit insensitive behaviors to students and education-teaching processes. Teachers have no intention of dealing with students and effectively handling the course and do not care neither students nor learning process. Such teacher behaviors can easily be explained by the lack of effective communication skills and low-level motivation. A teacher without effective communication skills is not capable of choosing the appropriate behavior for the situations they face from her repertoire of communicative behaviors; cannot build empathy, create a healthy discussion ground, pay attention to their professional interests; are not interested in students participating in the communication process; do not consider the content and relationship dimension of the message; ignore the existence needs of students (Ergin, 2014). In addition, teachers with low levels of motivation constantly complain about working conditions, express their dissatisfaction with their salaries, take no initiative and responsibility, are indifferent to work and cannot enjoy their work (Belle, 2007). Therefore, it is highly probable that teachers who lack effective communication skills and have low-level motivation are observed to have indifferent classroom management profile.

\section{Conclusion and Suggestions}

In this research, examined the predictive role of teachers' communication skills and motivation levels on classroom management profiles, active-participative listening, intrinsic motivation and authoritative class management profile are the variables with the highest mean. The highest relations are positively between authoritative classroom management profile and effective communication skills and negatively between authoritarian classroom management profile and motivation. Effective communication skills predict authoritarian and laissez-faire classroom management profiles negatively and authoritative classroom management profile positively. Effective communication skills and motivation together predict only indifferent classroom management profile.

Based on the negative predictive role of effective communication skills on the authoritarian and laissez-faire classroom management profile and the positive predictive role of effective communication skills on authoritative classroom management profile, it is suggested to given teachers awareness training related to self-knowledge and effective communication, to fulfill applications related to empathy, active listening and I-language. Because of the fact that effective communication skills and motivation predict in different classroom management profile, besides the practices of improving the communication skills of the teachers mentioned above, it can be suggested to create a school climate that increases the motivation level of teachers, to take a participatory role in the management and operation, to create environments in which they feel valued and to raise awareness about the positive effects of 
teachers on students. In addition, the effect of teachers' effective communication skills and high motivation level on the students can be researched and contributed teachers to have these skills and high-level motivation.

\section{References}

Adair, J., 2013. Effective communication. İstanbul: Babiâli Culture Publishing.

Aküzüm, C. and G.S. Ozdemir, 2017. Investigation of the relationship between classroom teachers' communication skills and classroom management skills. Electronic Journal of Education Sciences, 6(12): 88-107.

Argon, T. and R. Erturk, 2013. Intrinsic motivations of primary school teachers and perceptions of organizational identity. Educational Administration: Theory and Practice, 2(19): 159-179.

Baumrind, D., 1966. Effects of authoritative parental control on child behavior. Child Development, 37(4): 887-907.Available at: https://doi.org/10.2307/1126611.

Belle, L.J., 2007. The role of secondary school principals in motivating teachers in the Flacq District of Mauritius. Unpublished Master Thesis, University of South Africa.

Biçaku, C.R., 2015. The relationship between motivation and other dimensions of classroom management and foreign language acquisition. European Journal of Research and Reflection in Educational Sciences, 3(4): 78-88.

Bull, S.L. and J.E. Solity, 1996. Classroom management: Principles to practice. London and New York: Routledge.

Buluş, M., A. Atan and S.H. Erten, 2017. Effective communication tools: A conceptual framework proposal and a scale development study. International Online Journal of Educational Sciences, 9(2): 575-590.Available at: https://doi.org/ 10.15345/iojes.2017.02.020.

Büyüköztürk, Ş., K.E. Cakmak, Ö.E. Akgün, Ş. Karadeniz and F. Demirel, 2008. Scientific research methods. Ankara: Pegem Academy Publishing.

Cubukçu, Z. and P. Girmen, 2008. Teachers' views on classroom management skills. Bilig, 44(1): 123-142.

Demirtaş, H., 2005. Fundamentals of classroom management. H. Kıran (Ed.), Effective Class Management. Ankara: Anı Publishing. pp: 1-33.

DiGiulio, R., 2000. Positive classroom management. Thousand Oaks, CA: Corwin Press.

Dreikurs, R., 1968. Psychology in the classroom. New York: Harper \& Row.

Ekici, G., 2004. The evaluation of classroom management profiles of elementary school teachers. Education and Science, 13 1(1): 50-60.

Eren, E., 2000. Organizational behavior and management psychology. Istanbul: Beta Publications.

Eren, U.Z., 2018. Management of teaching process. Ottekin Demirbolat (Ed.), Class management. Ankara: Pegem Akademi Publishing. pp: 93-178.

Ergin, A., 2014. Effective communication in education. 7th Edn., Ankara: Anı Publishing.

Ertürk, R., 2016. Teachers' work motivations. Journal of Education, Theory and Practical Research, 2(3): 1-15.

Gibson, J.L., J.M. Ivancevich and J.H. Donnelly, 1997. Organizations: Behaviour, structure, processes. Botson: Irvin.

Gordon, T., 2013. Effective teacher training. (Trans. S. Karakale). Istanbul: Profile Publisher.

Gorham, J. and D. Christophel, 1990. The relationship of teachers' use of humor in the classroom to immediacy and student learning. Communication Education, 39(1): 46-62.Available at: https://doi.org/10.1080/03634529009378786.

Güneş, F., 2007. Classroom management in constructivist approach [constructivist approach]. Ankara: Nobel Akademi Publishing.

Hackman, J.R. and G.R. Oldham, 1980. Work redesign. Massachusetts: Addison Wesley.

Han, J., H. Yin and W. Wang, 2015. Exploring the relationship between goal orientations for teaching of tertiary teachers and their teaching approaches in China. Asia Pacific Education Review, 16(4): 537-547.Available at: https://doi.org/10.1007/s 12564-015-9392-7.

Hein, V., F. Ries, V.F. Pires, A. Caune, A. Emeljanovas, E.J. Heszteráné and I. Valantiniene, 2012. The relationship between teaching styles and motivation to teach among physical education teachers. Journal of Sports Science and Medicine, 11(1): 123-130.

Ihtiyaroğlu, N., 2018. Analyzing the relationship between happiness, teachers' level of satisfaction with life and classroom management profiles. Universal Journal of Educational Research, 6(10): 2227 - 2237.Available at: https://doi.org/10.13189/ujer.2018.06102 1.

Javaid, N., 2009. Teacher motivation: An area of neglect. Paper Presented at the CIDA Pakistan Programme, Pakistan.

Jesus, N., De Saul and J. Conboy, 2001. A stress management course to prevent teacher distress. International Journal of Educational Management, 15(3): 131-137.Available at: https://doi.org/10.1108/09513540110384484.

Jones, F., 2007. Tools for teaching: Discipline•instruction•motivation. Santa Cruz, CA: F.H. Jones \& Associates.

Karasar, N., 2009. Scientific research method. Ankara: Nobel Akademi Publishing.

Kris, B., 1996. Teacher talk " what is your classroom management profile? Available from http://education,indiana.edu/cas/tt/vli2/what,html [Accessed 12.06.2018].

Ming-Tak, H. and L. Wai-Shing, 2008. Classroom management: Creating a positive learning environment. Hong Kong and Aberdeen: Hong Kong University Press.

Planalp, S., 1999. The intertwining of communication and emotion: A communications scientist's perspectives. New York: Cambridge University Press.

Slavin, R., 2013. Cooperative learning and achievement: Theory and research. In W. Reynolds, G. Miller, \& I. Weiner (Eds.), Handbook of psychology. Hoboken, NJ: Wiley. pp: 199-212.

Tauber, R.T., 2007. Classroom management: Sound theory and effective practice. Westport, Conn: Praeger Publishers.

Tulunay, A.Ö. and N. Ihtiyaroğlu, 2019. Adult motivation scale: A scale development study. Kastamonu Education Journal, 7(2).

Tuzcuoglu, S., 2014. Motivation. A. Bakioğlu (Ed.), Educational psychology. Ankara: Nobel Academic Publishing. pp: 299-320.

Yazıcıoğlu, Y. and S. Erdoğan, 2004. Spss applied scientific research methods. Ankara: Detay Publications.

Yilmaz, K., 2011. The relationship between primary school teachers' views on classroom management styles and democratic values. Journal of Values Education, 9(21): 147-170. 